\title{
Pelatihan Pengembangan Pembelajaran Berbasis Pendekatan Discovery Learning dan Inquiry Learning untuk Penguatan Ketrampilan Mengajar Guru SMKN 1 Lingsar, Lombok Barat dalam Melaksanakan Kurikulum 2013
}

\author{
Untung Waluyo $^{1 *}$, Wildan ${ }^{1}$, I Wayan Karta ${ }^{1}$, Hari Witono ${ }^{1}$ \\ ${ }^{1}$ Master of Education Administration Program, University of Mataram, Lombok, Indonesia
}

DOI: https://doi.org/10.29303/jpmsi.v3i1.105

Citation: Waluyo, U., Wildan, W., Karta, I. W., Witono, H. 2021. Pelatihan Pengembangan Pembelajaran Berbasis Pendekatan Discovery Learning dan Inquiry Learning untuk Penguatan Ketrampilan Mengajar Guru SMKN 1 Lingsar, Lombok Barat dalam Melaksanakan Kurikulum 2013. Jurnal Pengabdian Masyarakat Sains Indonesia (JPMSI). 3(1):213-218.

Article history

Received: April 09 2021

Revised: May $25^{\text {th }} 2021$

Accepted: June $20^{\text {th }} 2021$

*Corresponding Author: Untung Waluyo, MAP Master Program, Mataram, Indonesia; Email:

untungwaluyo@unram.ac.id
Abstrak: Sejalan dengan diberlakukannya Kurikulum tahun 2013 di sekolah di Indonesia, pola pengajaran deduktif (teaching-focused) berubah menjadi pola pengajaran induktif (learning-focused). Tantangan besar yang ditengarai menjadi sandungan keberhasilan pelaksanaan pembelajaran induktif adalah rendahnya pemahaman dan ketrampilan guru akan model pembelajaran berbasis pendekatan saintifik, seperti discovery dan inquiry learning. Karena kurangnya informasi tentang model pembelajaran induktif, para guru tak terlatih mengembangkan model-model pembelajaran induktif. Untuk membekali para guru dengan ketrampilan tersebut, kegiatan pengabdian ini dilaksanakan dalam bentuk workshop di SMKN 1 Lingsar, Kabupaten Lombok Barat. Tujuan dari kegiatan pengabdian pada masyarakat ini, diantaranya, adalah membekali keterampilan para guru SMKN 1 Lingsar dengan pengatahuan dan ketrampilan dalam merancang, mengembangkan dan menerapkan model pembelajaran discovery dan inquiry learning baik secara luring maupun daring; mengenalkan aneka model pembelajaran yang berorientasi pada pendekatan discovery dan inquiry learning di sekolah target; dan mengembangkan model pembelajaran induktif melalui pemanfaatan Learning Platform sebagai alternative pembelajaran dari rumah di masa pandemi. Metode yang digunakan adalah kegiatan pemecahan masalah, demonstrasi, refleksi dan tanya jawab. Hasil kegiatan pengabdian kepada masyarakat, mengungkap beberapa hasil yang positif, diantaranya seperti: (a) dihasilkannya draft model pembelajaran berbasis discovery dan inquiry learning yang dikembangkan oleh para peserta; (b) munculnya respons positif dari para peserta untuk memperdalam pengetahuan dan ketrampilan mereka dalam mengembangkan model pembelajaran induktif; dan (c) dari kegiatan curah gagasan dan kegiatan pemecahan masalah terungkap inisiatif untuk membuat rencana tindak lanjut pengembangan model pembelajaran induktif melalui pemanfaatan Learning Platform yang berbasis daring (online) dan (d) adanya permintaan dari para guru agar kegiatan serupa dilanjutkan di masa mendatang.

Kata kunci: Kurikulum 2013, Pendekatan Saintifik, Discovery Learning, Inquiry Learning.

menjadi pola pengajaran yang bertumpu pada siswa (teacher-focused). Dengan sendirinya, guru berbagai bidang studi di SMK dituntut mampu menguasai model-model pembelajaran baru yang melibatkan seluruh siswa dalam pembelajaran di
2013, pola pendekatan pengajaran yang bertumpu pada penjelasan guru (teacher-focused) berubah

\section{Pendahuluan}

Sejalan dengan diberlakukannya Kurikulum 
Waluyo et al, Jurnal Pengabdian Masyarakat Sains Indonesia 2021, 3 (1): 213-218. DOI: https://doi.org/10.29303/jpmsi.v3i1.105

kelas. Untuk mendukung pemberlakuan kebijakan Kurikulum 2013, Pemerintah Indonesia dalam ini Kementrian Pendidikan dan Kebudayaan telah menerbitkan berbagai buku pendamping kurikulum tersebut, seperti buku ajar, buku petunjuk pelaksanaan kurikulum, buku pendampingan guru, dan sebagainya (Permedikbud No, 105 Th. 2014). Di samping itu, pemerintah juga telah mengadakan berbagai kegiatan lokakarya, pelatihan, symposium dan sebagainya untuk memperkenalkan isi kurikulum, pendekatan dan model pembelajaran yang disarankan (Rohaeni \&. Jubaedah, tanpa tahun).

Akan tetapi hasilnya sejauh ini belum maksimal dan memuaskan semua pihak. Ada 2 isu besar yang ditengarai menjadi sandungan terhadap keberhasilan pelaksanaan pelatihan. Pertama, menurut Waluyo, Soepriyanti \& Wardana (2019), pemahaman dan ketrampilan guru akan model belajar berbasis discovery and inquiry learning di sekolah-sekolah di pulau Lombok masih sangat rendah. Banyak guru belum sepenuhnya menguasai cara mengembangkan dan menyampaikan materi pembelajaran model discovery and inquiry learning kepada siswa. Karena minimnya pengetahuan mereka akan model belajar discovery and inquiry learning, dalam merespons kebijakan penerapan Kurikulum 2013 umumnya mereka tergantung pada buku paket tanpa mengembangkan materi ajar lebih jauh. Akibatnya pelaksanaan kegiatan belajar mengajar di sekolah tidak berjalan sesuai dengan harapan Kurikulum 2013 (Zendrato, 2016). Dalam proses kegiatan mengajar di kelas, misalnya, guru masih menggunakan metode dan pendekatan belajar konvensional yang monotoon dan membosankan sehingga terjebak dalam komunikasi satu arah.

Kenyataan ini mengisyaratkan bahwa penguasaan metode dan strategi belajar baru yang berbasis discovery and inquiry learning menjadi kebutuhan mendesak yang harus dikuasai guru. Sebagai pelaksana kurikulum di garda depan, guru dituntut menguasai beraneka ragam teknik dan strategi belajar mengajar. Terlepas dari gambaran ideal di atas, kenyataan di lapangan menunjukkan bahwa upaya pemerintah untuk memfasilitasi guru dalam mengembangkan materi ajar dengan pendekatan discovery and inquiry learning di sekolah masih terbatas. Pada umumnya, pelatihan dan lokakarya yang diselenggarakan oleh pihak Kementrian Pendidikan dan Kebudayaan setempat
e-ISSN : 2715-2537

p-ISSN : 2715-2545

masih terbatas pada ceramah-ceramah umum tentang Kurikulum 2013 (Winingsih, 2016), dan tidak terkait langsung dengan bagaimana cara mengembangkan materi ajar dengan model pendekatan discovery and inquiry learning. Pelatihan seperti ini tentunya tidak banyak memberikan kontribusi yang berarti bagi pengembangan kompetensi pedagogis guru. Oleh karenanya, sangatlah beralasan jika pelatihan pengembangan materi discovery and inquiry learning bagi guru-guru di SMKN 1 Lingsar perlu diberikan melalui kegiatan pengabdian kepada masyarakat.

Isu yang ke dua berkenaan dengan tidak tersedianya pelatihan sejenis bagi guru SMK secara umum. Sejauh ini, pelaksanaan Kurikulum 2013 telah berjalan kurang lebih selama 8 tahun akan tetapi hingga kini pelatihan formal untuk menyiapkan guru-guru agar mampu mengembangkan materi discovery and inquiry learning boleh dikatakan belum begitu banyak. Karena kurangnya pengetahuan dan ketrampilan guru dalam mengembangkan materi ajar discovery and inquiry learning, di sana sini masih ditemukan guru yang tidak dapat melaksanakan kegiatan belajar sesuai dengan tuntutan Kurikulum 2013. Dari persoalan di atas, dapat disimpulkan bahwa agar tercapai proses implementasi Kurikulum 2013 sesuai dengan desain yang diamanatkan oleh Pemerintah, maka dibutuhkan sebuah kegiatan pelatihan komprehensif yang dapat membuka wawasan para guru dalam mengembangan materi untuk pendekatan discovery and inquiry learning.

Kegiatan pengabdian pada masyarakat ini dilaksanakan dalam rangka merespons problema pengembangan materi ajar dengan pendekatan discovery and inquiry learning sebagaimana dijelaskan di atas. Melalui kegiatan ini, para guru peserta lokakarya diharapkan dapat memperoleh ketrampilan tentang cara-cara mengembangkan materi ajar dengan pendekatan discovery and inquiry learning. Dengan demikian, hasil pelatihan ini dapat digunakan sebagai sumber rujukan untuk mengembangkan suplemen model pembelajaran di sekolah. Melalui pelatihan ini, para guru diharapkan mampu membuat inovasi baru dalam menyampaikan materi belajar bidang ilmu mereka dengan bertumpu pada kegiatan kolaborasi antar siswa di dalam kelas. Dengan demikian, dalam jangka panjang, pengetahuan dan ketrampilan tersebut akan membentuk kompetensi profesional 
Waluyo et al, Jurnal Pengabdian Masyarakat Sains Indonesia 2021, 3 (1): 213-218. DOI: $\underline{\text { https://doi.org/10.29303/jpmsi.v3i1.105 }}$

guru di dalam mengembangkan materi ajar yang sejalan dengan kurikulum baru.

Sejumlah publikasi ilmiah menunjukkan bahwa secara umum penerapan Kurikulum 2013 masih mengalami kendala di sana sini. Di tingkat sekolah, pemahaman dan interpretasi guru terhadap konsep dan penerapan Kurikulum 2013 beragam sehingga pelaksanaan di tingkat sekolah pun saling berlainan. Sebagai contoh, Sukirno (2014) melaporkan bahwa penerapan Kurikulum Bahasa Inggris 2013 di Sekolah Menengah Pertama Kajen 1, Jawa Tengah, mengalami kendala karena guru tidak sepenuhnya memahami cara menerapkan pendekatan saintifik dan model-model pembelajaran deduktif (learning centered) sebagaimana yang disarankan oleh Kurikulum 2013. Akibatnya, siswa mengalami kesulitan untuk berpartisipasi dalam proses pembelajaran meskipun guru telah berupaya untuk membuat kegiatan pembelajaran interaktif. Dalam hal yang senada, Bulan dan Suryaman (2018) memaparkan bahwa guru-guru SMA di Sleman Jawa Tengah menghadapi beberapa kendala dalam mengimplementasikan Kurikulum 2013. Munculnya kendala tersebut, diantaranya, karena (1) terlalu guru dibebani dengan banyaknya pekerjaan administrasi yang tidak praktis, (2) kurangnya pengetahuan dalam menerapkan pendekatan saintifik beserta model-model pembelajarannya, (3) kurangnya buku pegangan siswa dan (4) kurangnya keahlian guru dalam memberikan penilaian otentik.

Situasi di atas terjadi karena kurangnya informasi, pemahaman dan ketrampilan guru dalam menerapkan pendekatan saintifik beserta modelmodel pembelajar kolaboratif yang dianjurkan oleh Kurikulum 2013. Sejumlah bukti empiris mendukung proposisi ini. Ahmad dan Mardiana (2014), misalnya, melakukan penelitian tentang persepsi dan interpretasi guru terhadap Kurikulum Bahasa Inggris 2013 di empat Sekolah Menengah Atas di Makassar. Hasil penelitian mereka menunjukkan bahwa guru memiliki persepsi positif tentang datangnya kurikulum baru. Namun, pemahaman mereka terhadap kurikulum baru hanya terjadi pada tataran kognitif. Untuk tataran penerapan kurikulum, sebagian besar kompetensi guru masih kurang memadai. Temuan penelitian serupa dilaporkan oleh Azizah dkk. (2015) yang melakukan studi kualitatif tentang penerapan pendekatan saintifik di pulau Madura. Hasil
e-ISSN : 2715-2537

p-ISSN : 2715-2545

penelitian mereka menunjukkan bahwa secara konseptual guru memiliki pengetahuan yang baik tentang pembuatan rencana pelaksaan pembelajaran dengan langkah-langkah pendekatan saintifik, dan model maupun strategi pembelajarannya. Namun dalam praktiknya, para guru tersebut tidak sepenuhnya menguasai cara mengaplikasikan pendekatan tersebut dalam kegiatan belajar mengajar yang sebenarnya. Mereka cenderung kembali menggunakan pembelajaran deduktif (teaching centered) yang menekankan guru mendominasi penjelasan ketimbang siswa belajar mencari pengalaman dari langkah-langkah pendekatan saintifik.

\section{Metode}

Khalayak sasaran kegiatan pengabdian pada masyarakat ini adalah para guru SMKN Lingsar. Pelaksanaan kegiatan pengabdian pada masyarakat ini bertempat di sekolah tersebut dengan seijin kepala sekolah mitra. Jumlah khalayak sasaran kegiatan yang diundang untuk menghadiri kegiatan lokakarya kegiatan ini adalah 30 orang tetapi yang hadir 25 orang dari sejumlah bidang studi yang ada di sekolah tersebut. Pengajar dan narasumber untuk kegiatan ini adalah dosen-dosen yang mengajar di Program Magister Administrasi, Universitas Mataram yang telah berpengalaman memberikan pelatihan di bidang Kurikulum 2013.

Kegiatan pelatihan ini melibatkan para guru bidang studi bahasa dan ilmu-ilmu sosial melalui kerja kelompok dalam rangka memecahkan kesulitan-kesulitan yang mereka hadapi di dalam mengembangkan materi ajar yang berbasis discovery dan inquiry learning. Melalui kegiatan ini pula mereka belajar tentang cara mengevaluasi tingkat keberhasilan mereka di dalam mengembangkan/memodifikasi bahan ajar yang dihasilkan

Dari analisis situasi didentifikasi kebutuhan mendesak yang diperlukan oleh para guru SMKN 1 Lingsar adalah kemampuan dan ketrampilan dalam menciptakan bahan ajar yang berbasis discovery and inquiry learning. Dengan diperolehnya pengetahuan dan ketrampilan dari kegiatan pengabdian ini, mereka dapat melaksanakan pengajaran bidang ilmu mereka sesuai dengan amanat Kurikulum 2013. Untuk kegiatan tersebut, metode pelaksanaan kegiatan pengabdian pada masyarakat ini adalah melalui pelatihan 
Waluyo et al, Jurnal Pengabdian Masyarakat Sains Indonesia 2021, 3 (1): 213-218. DOI: $\underline{\text { https://doi.org/10.29303/jpmsi.v3i1.105 }}$

pembekalan pengetahuan dan ketrampilan bagi para guru SMKN 1 melalui pelatihan pengembangan materi ajar yang berbasis discovery and inquiry learning

Dalam kegiatan pelatihan pengembangan materi ajar dan penerapan model discovery learning dan inquiry, tim pengabdian membagi peserta lokakarya dalam kelompok dan menugaskan mereka untuk mengamati contoh-contoh discovery learning dan inquiry yang ditayangkan oleh tim pengabdian melalui Google Classroom platform. Selanjutnya, para peserta lokakarya ini bekerja bersama untuk mendiskusikan karakteristik model dan cara penyajiannya. Mereka mengkritisi model discovery learning dan inquiry yang ditayangkan. Kegiatan selanjutnya adalah peserta pelatihan belajar mempraktekkan cara mengajarkan materi yang mereka kembangkan sesuai dengan petunjuk dan rambu-rambu yang diberikan oleh tim pengabdian. Pada akhir kegiatan, masing-masing kelompok akan mempresentasikan hasil kerja bersama terkait dengan pengembangan model pembelajaran discovery learning dan inquirry yang dapat digunakan untuk menerapkan pembelajaran induktif di sekolah mereka.

\section{Hasil dan Pembahasan}

Pada sesi pertama pelaksanaan kegiatan pengabdian pada masyarakat, tim pelaksana memaparkan materi pendahuluan yang berhubungan dengan masalah-masalah penerapan model pembelajaran berbasis discovery learning dan inquiry melalui daring di saat pandemi. Kemudian, pada sesi kedua, disampaikan materi tentang rasional, konsep, manfaat dan cara pengembangan model pembelajaran discovery learning dan inquiry melalui sistem manajemen belajar Google Classroom. Pada sesi utama, pemateri mendemonstrasikan materi penerapan model discovery learning dan inquiry sebagai medium untuk meningkatkan pemahaman dan partisipasi siswa dalam pembelajaran kolaboratif. Kegiatan ini dilanjutkan dengan kegiatan kerja kelompok. Pada kegiatan ini, para peserta workshop melakukan refleksi bersama untuk mengidentifikasi permasalahan yang terkait dengan pengalaman dan kesulitan mereka dalam menerapkan model pembelajaran discovery learning dan inquiry. Mereka menyampaikan permasalahan pokok yang mereka hadapi dalam
e-ISSN : 2715-2537

p-ISSN : 2715-2545

mengembangkan model pembelajaran discovery learning dan inquiry yang berbasis daring. Selama kegiatan berlangsung peserta memperlihatkan rasa ingin tahu yang tinggi tentang cara pengembangan materi discovery learning dan inquiry yang dirancang untuk kelas daring.

Sejumlah peserta berpendapat bahwa materi yang diberikan sejalan dengan kebutuhan mereka. Kegiatan ini dilanjutkan dengan sesi tanya jawab. Selama kegiatan ini berlangsung, mayoritas peserta terlibat aktif dalam interaksi dengan tim pelaksana pengabdian. Tim pengabdian memfasilitasi kegiatan pemecahan masalah melalui aktivitas problem solving cara mengembangkan materi belajar model discovery learning dan inquiry melalui sistem manajemen belajar Google Classroom. Pasca kegiatan workshop, tim pengabdian menyebarkan angket evaluasi kegiatan kepada peserta dengan menggunakan Google Form. Hasil angket menunjukkan bahwa bahwa 85\% peserta memahami konsep pengembangan model discovery learning dan inquiry melalui daring yang disampaikan oleh tim pengabdian pada masyarakat. Sebagian besar peserta mengakui manfaat kegiatan bagi diri sendiri, siswa dan sekolah. Temuan penting dari kegiatan workshop ini adalah adanya pemahaman bersama tentang cara mengembangkan model materi ajar discovery learning dan inquiry yang berbasis daring di SMKN 1 Lingsar.

Berdasarkan angket evaluasi tersebut juga diperoleh informasi dari mayoritas peserta workshop bahwa pelatihan sejenis perlu dilanjutkan di masa mendatang karena mereka menganggap kegiatan serupa perlu dipertahankan kesinambungannya. Pada umumnya, peserta workshop menyatakan kepuasan dan apresiasi yang sangat tinggi dengan perolehan ketrampilan dari kegiatan pengabdian pada masyarakat ini. Sebagian besar dari mereka menyarankan agar ada kegiatan pendampingan dari tim pengabdian supaya mereka dapat belajar tuntas tentang pengembangan materi ajar dengan model discovery learning dan inquiry yang berbasis daring. Mereka berharap kegiatan pendampingan ini dapat meningkatkan ketrampilan dan kompetensi pedagogis mereka. Secara umum dapat disimpulkan bahwa dampak jangka pendek dari pelatihan ini adalah meningkatnya pemahaman, pengetahuan dan keterampilan guru dalam menerapkan model discovery learning dan inquiry yang berbasis daring. 
Waluyo et al, Jurnal Pengabdian Masyarakat Sains Indonesia 2021, 3 (1): 213-218. DOI: $\underline{\text { https://doi.org/10.29303/jpmsi.v3i1.105 }}$

Sebagian besar dari peserta workshop ini menyarankan bahwa tim pengabdian perlu memperluas cakupan kegiatan serupa dengan melibatkan sekolah dan pesantren yang ada di sekitar wilayah mereka. Mereka menjelaskan bahwa banyak guru yang kesulitan mengembangkan materi ajar pembelajaran daring dengan model discovery learning dan inquiry. Salah seorang peserta workshop menyampaikan bahwa saat ini di pondok-pondok pesantren di daerah tempat tinggalnya (Narmada) penerapan model discovery learning dan inquiry hanya sekadar menjadi jargon formal saja. Pada umumnya para guru atau ustadz di tempat mereka masih menggunakan pembelajaran deduktif di dalam melaksanakan Kurikulum 2013. Karena kurangnya pengetahuan dan ketrampilan mereka dalam mengembangkan model pembelajaran deduktif seperti discovery learning dan inquiry, penerapan Kurikulum 2013 masih sebatas "sekadar kenal istilah". Seringkali guru tidak mengetahui persisnya cara mengajar induktif sebagaimana yang diamanatkan oleh Kurikulum 2013. Oleh karenanya, para peserta menyarankan bahwa sosialisasi pengembangan materi daring dengan model discovery learning dan inquiry perlu dilakukan ke sekolah sekolah lain.

Kegiatan pelatihan ini berjalan lancar sesuai dengan yang direncanakan oleh tim pengabdian dan pihak tuan rumah, yaitu SMKN 1 Lingsar. Ada tiga faktor utama yang mendukung kelancaran kegiatan pengabdian ini. Pertama, Tersedia tenaga ahli dari tim pengabdian yang menguasai bidang pembelajaran daring dan Kurikulum 2013. Kedua, disiplin peserta workshop. Para peserta tiba melakukan registrasi di tempat pelatihan 30 menit sebelum kegiatan berlangsung meskipun sebagian besar dari mereka tinggal jauh dari lokasi pengabdian. Ketiga, rasa ingin tahu dan partisipasi dari peserta sangat tinggi. Selama kegiatan pelatihan berlangsung, banyak peserta mengajukan pertanyaan atau memberikan komentar terhadap materi yang disampaikan oleh pemateri.

Secara umum, terdapat dua faktor penghambat yang berarti selama kegiatan lokakarya berlangsung, yaitu: (1) peserta pelatihan banyak yang tidak membawa perangkat seperti laptop sehingga mereka harus menggunakan android untuk berlatih membuat materi ajar daring; (2) waktu pelaksanaan kegiatan yang terbatas sehingga tidak semua peserta dapat menayangkan hasil
e-ISSN : 2715-2537

p-ISSN : 2715-2545

pembelajaran mereka di depan sejawatnya. Untuk itu, tim memafasilitasi peserta dengan membuatkan Google Classroom sebagai wadah komunikasi dengan peserta pelatihan.

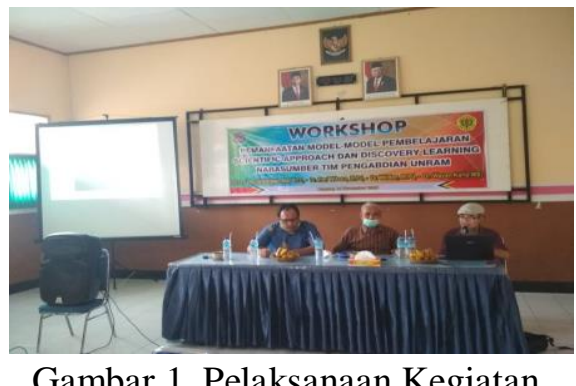

Gambar 1. Pelaksanaan Kegiatan

\section{Kesimpulan}

Kegiatan pelatihan pengabdian pada masyarakat yang berbentuk workshop ini bertujuan untuk meningkatkan kemampuan guru dalam mengembangkan materi daring dengan model discovery learning dan inquiry. Indikator keberhasilan pencapaian tujuan ini dapat dilihat dari: (a) adanya kesesuaian materi pelatihan dengan kebutuhan guru untuk meningkatkan kapasitas dan kompetensi pedagogis guru di masing-masing bidang studi; (b) meningkatnya pemahaman yang signifikan dari peserta workshop terhadap cara mengembangkan model pembelajaran discovery learning dan inquiry secara daring; (c) terbentuknya draft model pembelajaran discovery learning dan inquiry dalam bentuk digital yang dapat diakses oleh guru dan siswa melalui Google Classroom.

\section{Saran}

Peserta pelatihan menyarankan agar ada kegiatan monitoring dan penguatan dari tim pengabdian setelah workshop selesai. Mereka juga menyarankan agar kegiatan serupa dapat dilaksanakan bagi rekan sejawat mereka yang belum mendapat mengikuti workshop pemanfaatan daring sebagai medium pengembangan model pembelajaran discovery learning dan inquiry

\section{Ucapan Terima Kasih}

Ucapan terima kasih dan penghargaan disampaikan kepada Rektor Universitas Mataram, melalui ketua LPPM Unram, atas dukungan 
Waluyo et al, Jurnal Pengabdian Masyarakat Sains Indonesia 2021, 3 (1): 213-218. DOI: https://doi.org/10.29303/jpmsi.v3i1.105

finansial dan terselenggaranya kegiatan pengabdian ini.

\section{Daftar Pustaka}

Ahmad, J. \& Mardiana. 2014. "Kurikulum 2013 dalam Persepsi dan Interpretasi Guru-Guru Bahasa Inggris SMA di Kota Makassar" BAHTERA: Jurnal Pendidikan Bahasa dan Sastra, Tahun 13, No. ljanuari 201473

Azizah, S Widodo, A. \& Adriana. I. 2015. Implementasi Pendekatan Scientific dalam Pengajaran Bahasa Inggris Kurikulum 2013 di SMPN 1 Pamekasan. OKARA, Vol. 2, Tahun X, Nopember 2015

Bulan, Arif and Suryaman, Maman. 2018 Implementasi Kurikulum 2013 pada Mata Pelajaran Bahasa Inggris Sekolah Menengah Atas Negeri di Kabupaten Sleman. S2 thesis, UNY.

Gonzales, R., P. 2018. Digital Image Processing (Pemrosesan Citra Digital), Vol. 1, Ed.2, diterjemahkan oleh Handayani, S. Andri Offset: Yogyakarta.

Kristin, F. 2016. "Analisis Model Pembelajaran Discovery Learning dalam Meningkatkan Hasil Belajar Siswa SD”. Jurnal Pendidikan Dasar PerKhasa, Vol, 2 (1). Hal. 80-98

Martaida, T., Bukit, N. \& Ginting, E.M. 2017. "The Effect of Discovery Learning Model on Student's Critical Thinking and Cognitive Ability in Junior High School". IOSR Journal of Research \& Method in Education (IOSR-JRME). Vol. 7 (6). Hal. 01-8

Rohaeni, N., and Y. Jubaedah (n.d.). Model Desain Kurikulum Pelatihan Profesi Guru Vokasional Berbasis Technological Curriculum. Jurusan PKK, FPTK, UPI.

Sanjaya, W. 2006. Strategi Pembelajaran Berorientasi Standar Proses Pendidikan. Rawamangun-Jakarta: Kencana Perdana MediaGroup.

Sukirno, S. 2014. The implementation of curriculum 2013 in the English language teaching and learning at SMP 1 Kajen Pekalongan. S2 thesis, UNY

Waluyo, U, Soepriyanti, H. \& Wardana, L.A. 2019. "Studi Eksplorasi Kompetensi Pedagogis Guru Bahasa Inggris di Sekolah Menengah Pertama (SMP) Kabupaten Lombok Timur dalam Menerapkan Model-Model
e-ISSN : 2715-2537

p-ISSN : 2715-2545

Pembelajaran berbasis Kurikulum 2013". Laporan Penelitian Universitas tahun 2019.

Winingsih, L.H. 2016. "Peran Pemerintah Daerah Dalam Implementasi Kurikulum 2013". Jurnal Pendidikan dan Kebudayaan, Vol. 1(1). Hal. 37-57

Zendrato, J. 2016. "Tingkat Penerapan Rencana Pelaksanaan Pembelajaran dalam Pelaksanaan Pembelajaran di Kelas: Suatu Studi Kasus di SMA Dian Harapan Jakarta”. Scholaria, Vol. 6 No. 2, Mei 2016: 58 - 73 